\title{
都市高速道路の交通特性に基づく 斜張橋の活荷重に関する研究
}

\author{
西岡 勉 1 堀江 佳平 $2 \cdot$ 明田 修3 \\ 1正会員 阪神高速道路（株）技術部（† 541-0056 大阪市中央区久太郎町4-1-3） \\ E-mail: tsutomu-nishioka@hanshin-exp.co.jp \\ 2正会員 阪神高速道路（株）技術部（干541-0056大阪市中央区久太郎町4-1-3） \\ E-mail: yoshihei-horie@hanshin-exp.co.jp \\ 3正会員（株）綜合技術コンサルタント（† 533-0033 大阪市東淀川区東中島3-5-9） \\ E-mail: o-aketa@sogo-eng.co.jp
}

\begin{abstract}
中央支間長 $600 \mathrm{~m}$ 斜張橋を対象に都市高速道路の交通特性，特に都市部で頻繁に発生する渋滞特性を 反映した設計活荷重を提案することを目的として車両列載荷のシミュレーションを実施した。シミュレー ション結果と等価L荷重を影響線の着目符号側のみに載荷する現行設計法の比較を行い, 影響線の着目符 号側と異符号側の面積比が両者の活荷重応答の差の要因であることを示した．性能照査型設計の観点から 地域の都市高速道路の交通特性に即した合理的な設計活荷重とその載荷方法を提案し, 死荷重+活荷重時 の終局限界状態に関する安全性評価指標の比較を行い，提案設計法の合理性を示した。
\end{abstract}

Key Words : traffic live load, cable-stayed bridge, urban expressway traffic survey, Monte Carlo simulation

\section{1. はじめに}

日本の道路橋の設計活荷重は，道路構造令第35条(1)の 規定を受け，設計自動車荷重を245kNとし，これに大型 車の交通状況を勘案して定められている．道路橋の主桁 を設計する場合は，2種類の等分布荷重 $p_{1}, p_{2}$ から成る自 動車荷重であるL荷重が載荷される，着目点または部材 に最も不利な応力が生じる位置に大型車を連行させて載 荷し，その周囲にはその他の車両を載荷する考え方であ $ろ^{2)}$.

支間長 $200 \mathrm{~m}$ を超える長大橋に対しても，上記のL荷重 の考え方を踏襲した等価L荷重 ${ }^{3}$ が用いられている．等 価L荷重では，支間長 $200 \mathrm{~m}$ に対応する等分布荷重 $p_{2}$ を $200 \mathrm{~m}$ 超の支間長に無制限に適用寸ることが合理的でな いので，支間長 $500 \mathrm{~m}$ 超える範囲では等分布荷重 $p_{2}$ を支 間長と車線数に応じて低減させている3゙.

一方で，道路橋の設計活荷重とその載荷方法に関する 研究が過去から実施されており, 実態の交通調査データ をもとに確率的な活荷重モデルを作成し，橋梁モデルに 車両列を載荷するモンテカルロシミュレーション解析に よって設計活荷重の妥当性について考察している．明 田・北沢 ${ }^{4}$ は，支間長 $40 \sim 500 \mathrm{~m}, 1 \sim 4$ 車線の単純桁橋及
び斜張橋を対象に車両列載荷のシミュレーション解析を 実施し，最大応答を示寸車両列の載荷状態が支間長，車 線数の増加に伴い, 通常走行よりも渋滞に大きく影響を 受けることを示している. 北田ら $ら^{51}$ は, 連続箱桁橋と斜 張橋を対象に同様のシミュレーション解析を行い, 着目 点または部材に最も不利な応力が生じる載荷法として, 影響線の着目符号側の夕に活荷重を載荷寸る設計法（以 下，影響線載荷法と呼ぶ．）がかなり安全側の設計にな ることに言及している。齊藤らの゙，4径間連続吊橋を対 象に車両列載荷のシミュレーションを行い，現行の等価 L荷重を影響線載荷する方法が実際の車両列の載荷状態 と比較して過大であることを示している.

本研究の目的は，中央支間 $600 \mathrm{~m}$ の斜張橋を対象とし て, 都市高速道路の交通特性，特に都市部で頻繁に発生 する渋滞特性を反映した設計活荷重を提案することであ る. 利用可能な交通調査データをもとに，地域の都市高 速道路の交通特性を可能な限り忠実にモデル化し，車両 列載荷のモンテカルロシミュレーション解析を行う。対 象とする斜張橋は, 大阪湾岸道路西伸部に計画中の橋長 $1,320 \mathrm{~m}$ （中央支間 $600 \mathrm{~m}$ ）の斜張橋である. 長大橋に適用 される等価L荷重を影響線載荷寸る設計法（以下，現行 設計法と呼ぶ。）とシミュレーション結果を比較し，性 


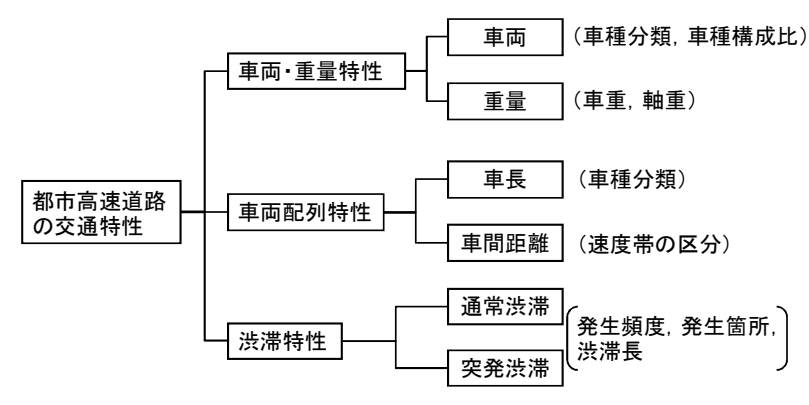

図-1 都市高速道路の交通特性

能照査型設計の観点から地域の都市高速道路の交通特性 に即した合理的な設計活荷重とその載荷方法を提案する. 最後に, 死荷重+活荷重時の終局限界状態を対象とした 安全性評価指標の比較から提案設計法の合理性について 言及する.

\section{2. 都市高速道路の交通特性のモデル化}

都市高速道路の交通特性として, 図-1に示寸ように車 両・重量特性，車両配列特性，渋滞特性を交通調査デー 夕に基づきモデル化する.

\section{（1）車両 · 重量特性}

車両・重量特性は，阪神高速道路ネットワークの中で 対象とする斜張橋の交通特性に最も近いと考えられる5 号湾岸線に着目し，1999年に5号湾岸線中島集約料金所 で実施した車両重量の調査データを用いてモデル化した. 車両は，図-2に示すように乗用車，中型車，大型車(2軸 及びタンデム軸), トレーラーに分類する.ささらに，大 型車(2軸及びタンデム軸)とトレーラーを空車，積載車， 過積載車の3種類に区分寸る. 5 号湾岸線の中島集約料金 所(上り線，大阪行き)及び南芦屋浜集約料金所(下り線, 神戸行き)における2005年11月から2006年1月の平日3日間 の大型車混入率の調査データを図-3(a), (b)に示す．上下 線とも深夜・早朝(0-6時)で60\%, 日中・夜間(6-24時)で 40\%とするとほぼ上限をカバーできるので，以下では大 型車混入率を深夜・早朝(0-6時) $60 \%$ ，日中・夜間(6-24 時) $40 \%$ と仮定する.

次に，車重実測データから確率分布モデルを作成する. 大型車タンデム軸を例に，車重実測データに確率分布を 当てはめた結果を図-4に，車重実測データと作成した確 率分布の比較を図-5に示寸，大型車タンデム軸の空車を 正規分布，積載車を対数正規分布，過積載車を指数分布

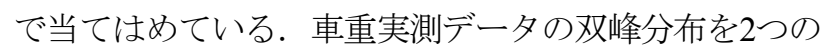

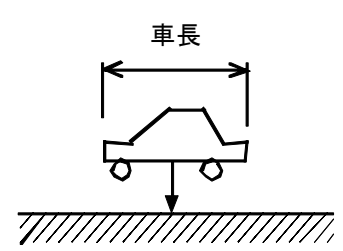

(a) 乗用車

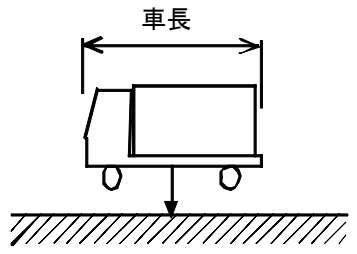

(b) 中型車

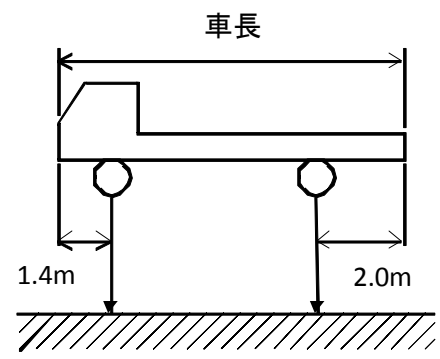

(c) 大型車 2 軸

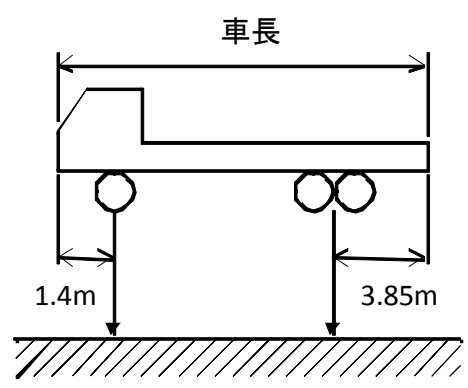

(d) 大型車タンデム軸

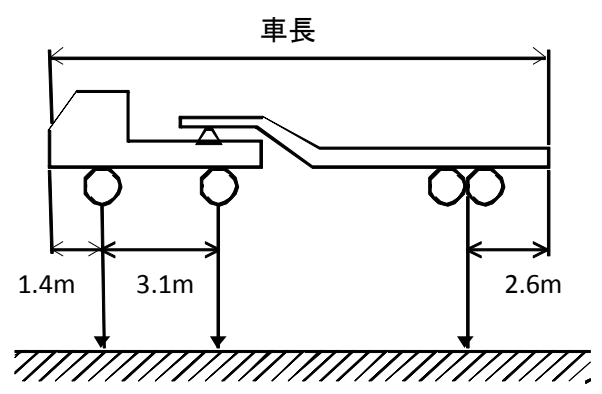

(e) トレーラー

図-2 車種分類

単峰分布の重㸚わせと見なし，それぞれに確率分布モ デルを当てはめ, 二乗誤差が最小となるように $2 つ の$ 確 率分布モデルの特性值と相対頻度の全体面積に対する比 率を定めた. なお，活荷重応答に影響が大きい分布の右 側の裾部は，より精度の高い当てはめを行うために裾切 りした指数分布で表した》。. 積載車と過積載車の境界值 は245 kNである．各車種の車重の確率分布モデルとその 


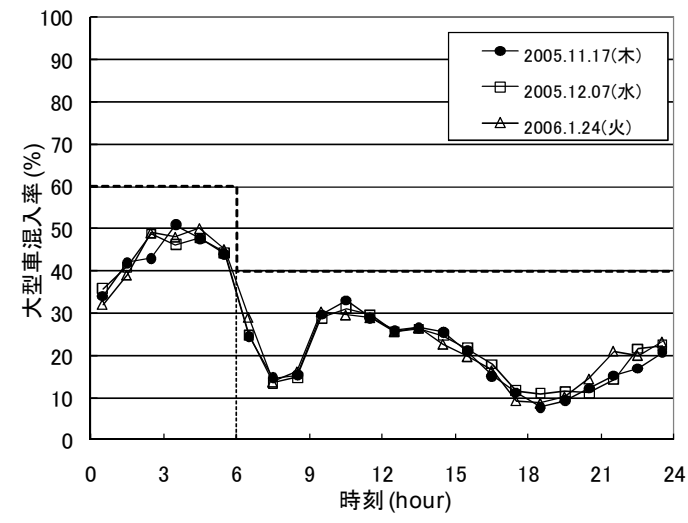

(a) 中島集約料金所(上り線，大阪行き)

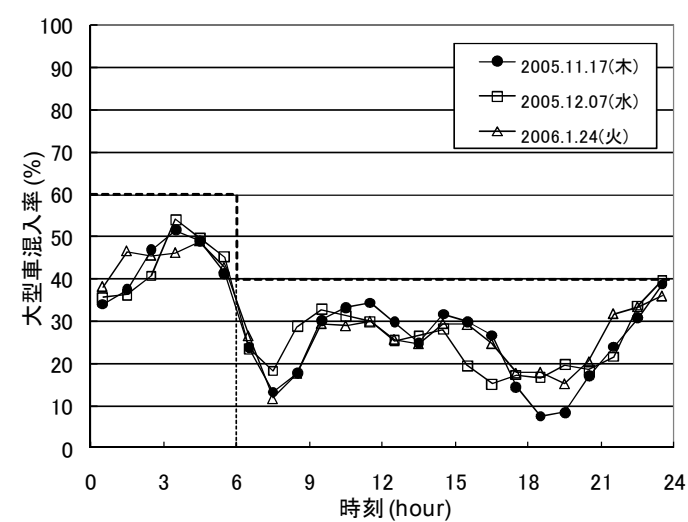

(b) 南芦屋浜集約料金所(下り線，神戸行き)

図-3 大型車混入率 (5 号湾岸線)

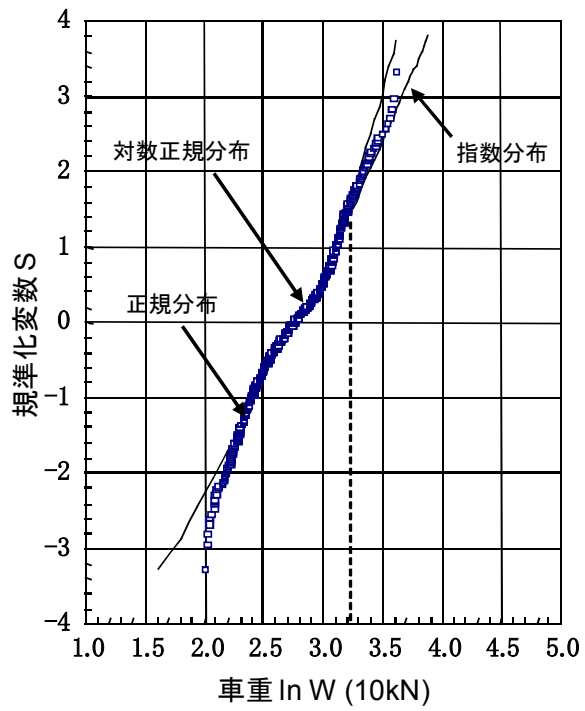

図-4 車重実測データの確率分布モデルの当てはめ（大型車夕 ンデム軸)

特性值を表-1に示す，車種分類と車種構成比を図-6に示 す. 車種構成比は, 大型車混入率の傾向が異なる日中・ 夜間(6-24時) と深夜・早朝(0-6時)で2種類に区分した．活 荷重モデルでは，図-2に示しているように乗用車，中型

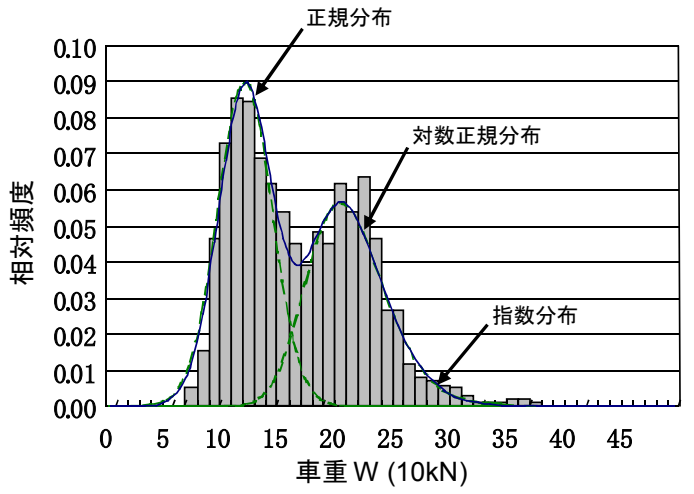

図-5 車重実測データと作成した確率分布の比較（大型車タンデ 八軸)

表-1＼cjkstart車重の確率分布モデルとその特性值

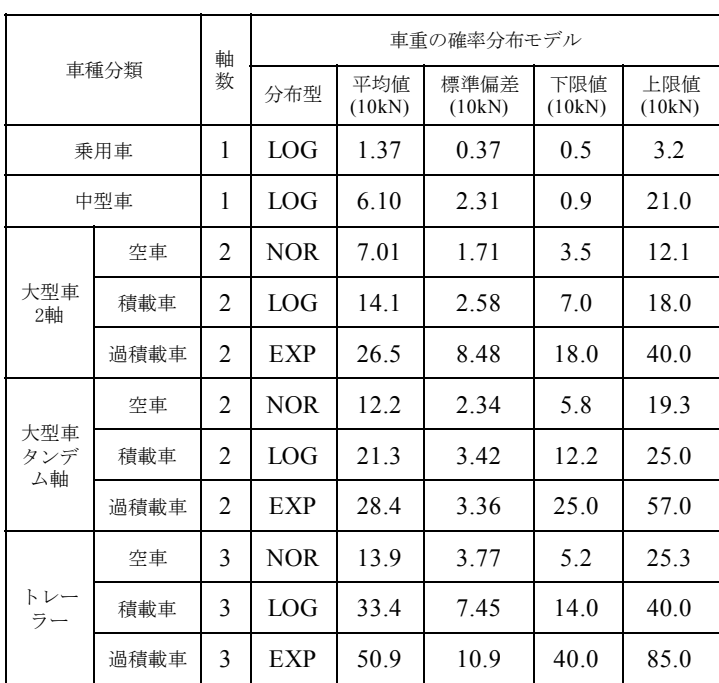

NOR : 正規分布
LOG : 対数正規分布
EXP : 指数分布

車を1軸の集中荷重，大型車(2軸及びタンデム軸)を2軸の 集中荷重，トレーラーを3軸の集中荷重とした．車重か ら2軸または3軸の集中荷重への変換は，車重と軸重デー タの相関分析の回帰式を用いる．大型車タンデム軸を例 に，車重と軸重の相関関係を図-7に示す，なお，軸位置 は自動車諸元表等を参考に，オーバーハングと軸間距離 を図-2に示したように設定している.

\section{(2) 車両配列特性}

車両配列特性は，1982～1983年の阪神高速道路の交通 調査データに基づくモデルわを用いた，各車種の車長の 確率分布モデルとその特性值を表-2に示す，上下限值を 有するべータ分布である. 車間距離の確率分布モデルと その特性值を表-3に示す。車間距離は，車両の走行速度 帯別の対数正規分布である. 車両の走行速度帯と走行状 態の関係は次節で説明する. 


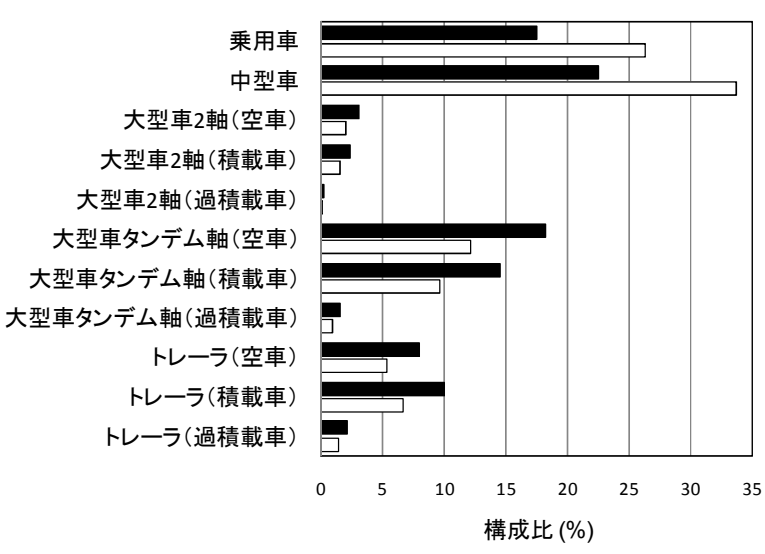

—深夜·早朝(0-6時) 口日中·夜間(6-24時)

図-6 車種分類と車種構成比（5 号湾岸線中島集約料金所）

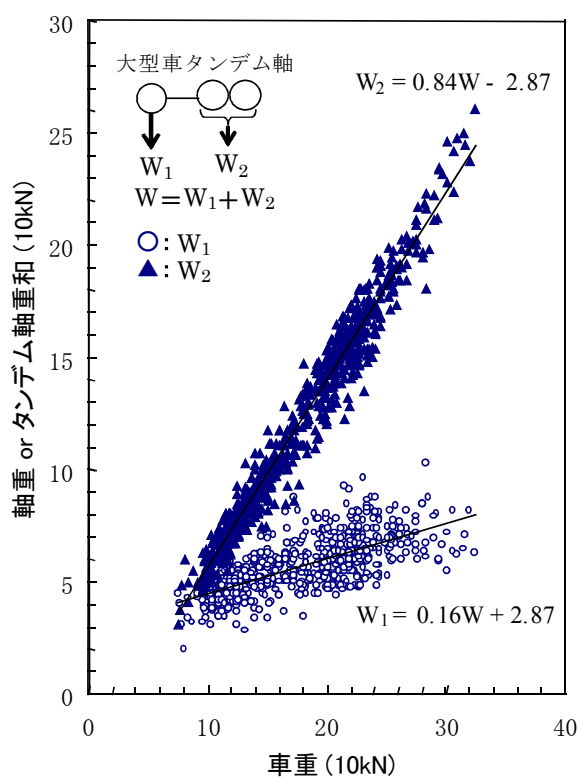

図-7 車重と軸重の相関関係（大型車タンデム軸）

\section{（3）渋滞特性}

啮滞特性は，阪神高速道路ネットワークで対象とする 斜張橋の交通特性に近く, 発生頻度等を安全側に評価で きると考えられる3号神戸線に着目し，2003〜2004年の2 年間の渋滞データを用いてモデル化する.

\section{a) 上下線の走行状態の組合せ}

都市高速道路の渋滞特性として, 朝夕のラッシュ時に 発生寸る通常渋滞と, 事故, 故障車, 道路工事等で発生 寸る突発渎滞の2種類の渋滞を考慮する. 都市高速道路 の上下線で，通常走行と2種類の渋滞を組合せた車両列 載荷のシミュレーションを行う。6ケースの走行状態の 組合せを表-4に示す. 各走行状態の組み合わせに大型車 表-2＼cjkstart車長の確率分布モデルとその特性值

\begin{tabular}{|c|c|c|c|c|c|}
\hline \multirow{2}{*}{ 車種分類 } & \multicolumn{5}{|c|}{ 車長の確率分布モデル } \\
\hline & 分布型 & $\begin{array}{c}\text { 平均值 } \\
(\mathrm{m})\end{array}$ & $\begin{array}{c}\text { 標隻偏差 } \\
(\mathrm{m})\end{array}$ & $\begin{array}{c}\text { 下限值 } \\
(\mathrm{m})\end{array}$ & $\begin{array}{c}\text { 上限值 } \\
(\mathrm{m})\end{array}$ \\
\hline 乗用車 & \multirow{5}{*}{$\begin{array}{l}\text { ベータ } \\
\text { 分布 }\end{array}$} & 4.0 & 0.38 & 3.0 & 5.0 \\
\hline 中型車 & & 6.2 & 1.58 & 3.5 & 12.0 \\
\hline $\begin{array}{c}\text { 大型車 } \\
\text { 2軸 }\end{array}$ & & 8.7 & 1.86 & 5.3 & 12.0 \\
\hline $\begin{array}{l}\text { 大型車夕 } \\
\text { ンデム軸 }\end{array}$ & & 10.4 & 1.23 & 6.4 & 12.0 \\
\hline $\begin{array}{l}\text { トレー } \\
\text { ラー }\end{array}$ & & 13.6 & 1.97 & 9.7 & 18.0 \\
\hline
\end{tabular}

表-3 車間距離の確率分布モデルとその特性值

\begin{tabular}{|c|c|c|c|}
\hline \multirow{2}{*}{ 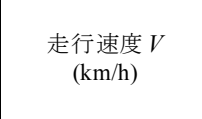 } & \multicolumn{3}{|c|}{ 車間距離の確率分布モデル } \\
\hline & 分布型 & $\begin{array}{c}\text { 平均値 } \\
(\mathrm{m})\end{array}$ & $\begin{array}{c}\text { 標準偏差 } \\
(\mathrm{m})\end{array}$ \\
\hline $\begin{array}{c}0 \leqq V \leqq 2 \\
\text { (突発啮滞に相当) }\end{array}$ & \multirow{3}{*}{$\begin{array}{l}\text { 対数正規 } \\
\text { 分布 }\end{array}$} & 2.71 & 1.49 \\
\hline $\begin{array}{c}10 \leqq V \leqq 30 \\
\text { (通常渋滞に相当) }\end{array}$ & & 8.05 & 3.93 \\
\hline $\begin{array}{c}45 \leqq V \\
\text { (通常走行に相当) }\end{array}$ & & 19.4 & 6.1 \\
\hline
\end{tabular}

表-4 渋帯を考慮した走行状態の組合せ

\begin{tabular}{|c|c|c|c|c|}
\hline Case & $\begin{array}{l}\text { 渋滞種別 } \\
\text { (上下線) }\end{array}$ & 時間帯 & $\begin{array}{l}\text { 大型車 } \\
\text { 混入率 }\end{array}$ & 年発生数 \\
\hline \multirow{2}{*}{1} & 通常走行 & \multirow{2}{*}{$\begin{array}{c}\text { 日中・夜間 } \\
(6-24 \text { 時) }\end{array}$} & \multirow{2}{*}{$40 \%$} & \multirow{2}{*}{730} \\
\hline & 通常渋滞 & & & \\
\hline \multirow{2}{*}{2} & 通常渋滞 & \multirow{2}{*}{$\begin{array}{c}\text { 日中・夜間 } \\
\text { (6-24時) }\end{array}$} & \multirow{2}{*}{$40 \%$} & \multirow{2}{*}{365} \\
\hline & 通常渋滞 & & & \\
\hline \multirow{2}{*}{3} & 通常走行 & \multirow{2}{*}{$\begin{array}{c}\text { 深夜・早朝 } \\
\text { (0-6時) }\end{array}$} & \multirow{2}{*}{$60 \%$} & \multirow{2}{*}{8} \\
\hline & 突発渋滞 & & & \\
\hline \multirow{2}{*}{4} & 通常走行 & \multirow{2}{*}{$\begin{array}{c}\text { 日中・夜間 } \\
(6-24 \text { 時) }\end{array}$} & \multirow{2}{*}{$40 \%$} & \multirow{2}{*}{75} \\
\hline & 突発渋滞 & & & \\
\hline \multirow{2}{*}{5} & 通常渋滞 & \multirow{2}{*}{$\begin{array}{c}\text { 日中・夜間 } \\
\text { (6-24時) }\end{array}$} & \multirow{2}{*}{$40 \%$} & \multirow{2}{*}{13} \\
\hline & 突発渋滞 & & & \\
\hline \multirow{2}{*}{6} & 突発渋滞 & \multirow{2}{*}{$\begin{array}{c}\text { 深夜 - 早朝 } \\
(0-6 \text { 時 })\end{array}$} & \multirow{2}{*}{$60 \%$} & \multirow{2}{*}{$\begin{array}{c}0.05 \\
\text { (1回/20年) }\end{array}$} \\
\hline & 突発渋滞 & & & \\
\hline
\end{tabular}

混入率の異なる時間帯を加味している.

Case 1とCase 2は，それぞれ，1方向のみの通常渋滞，2 方向とも通常渋滞のケースであり, 発生時間帯は日中・ 夜間(6-24時)である。通常渋滞は深夜・早朝(0-6時)に発 生しないと仮定している. Case 3 とCase 4は，いずれも1 方向の突発啮滞であるが，発生時間帯がそれぞれ，大型 車混入率の異なる深夜・早朝(0-6時), 日中・夜間(6-24 時)である. Case5は，1方向が通常啮滞，反対方向が突発 渋滞のケースである. Case6は，2方向とも突発渋滞のケ 一スであり，発生時間帯を大型車混入率が大きく活荷重 


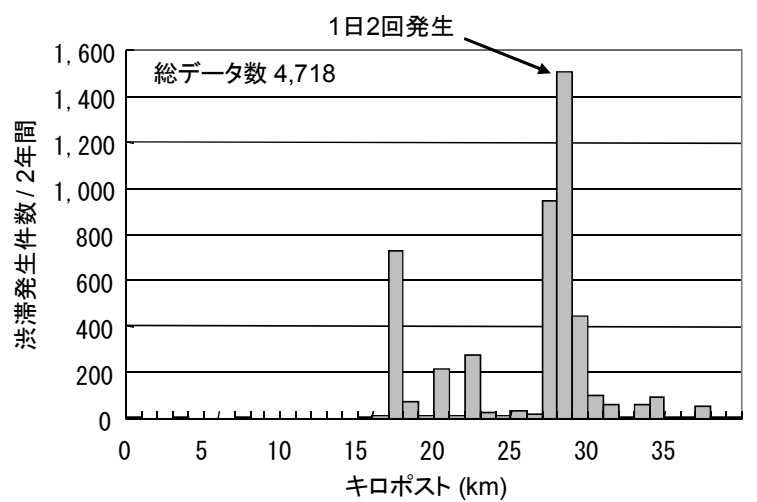

図-8２年間の通常渋滞の箇所別頻度（3号神戸線，日中・夜間 6-24時)

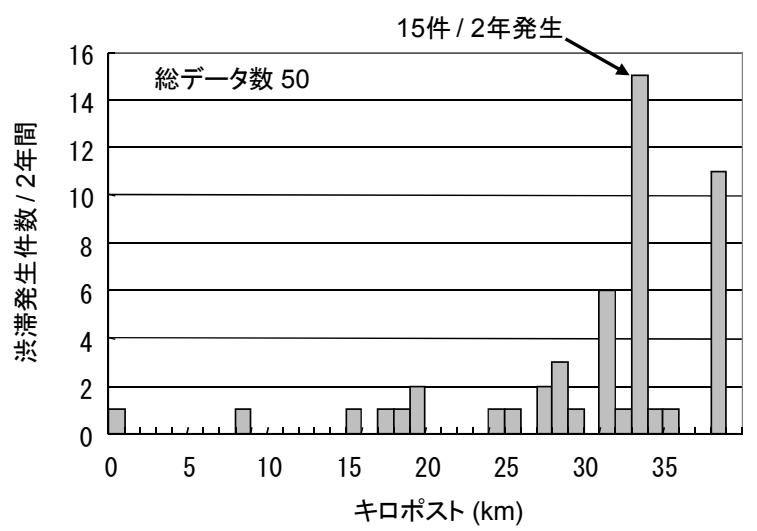

(a) 深夜 - 早朝(0-6 時)

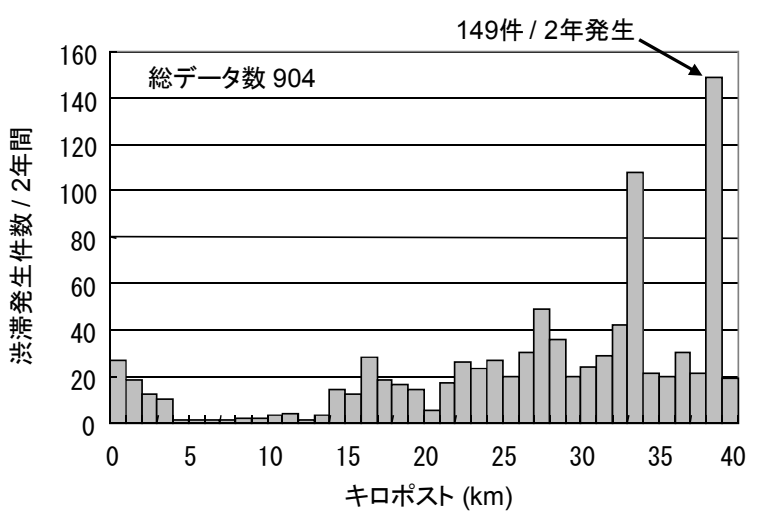

(b) 日中・夜間(6-24 時)

図-9 2 年間の突発渋滞の箇所別頻度 (3 号神戸線)

の載荷状態が厳しい深夜・早朝(0-6時)とした.

\section{b) 渋滞の年発生数}

2年間（2003～2004年）の3号神戸線の日中・夜間(6-24 時)における通常渋滞の箇所別頻度を図-8に示寸。横軸 は渋滞の発生位置を示寸キロポストである。28キロポス 卜付近でほぼ1日2回の渋滞が発生している。 このデータ をもとにCase 1の年発生数を730回/年(1日2回)と設定した.

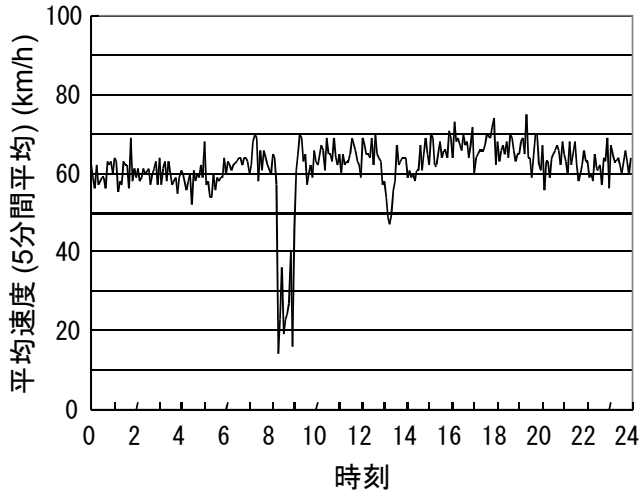

図-10 5分間平均速度の時刻変化（3号神戸線，芦屋一深江間)

表-5 車両速度, 車両列長の設定

\begin{tabular}{|c|c|c|}
\hline 走行状態 & $\begin{array}{c}\text { 走行速度 } \\
(\mathrm{km} / \mathrm{h})\end{array}$ & $\begin{array}{c}\text { 車両列長 } \\
(\mathrm{km})\end{array}$ \\
\hline 通常走行 & 60 & - \\
\hline 通常渋滞 & 30 & 45 \\
\hline 突発渋滞 & 2 & $\begin{array}{c}3 \text { (0-6時) } \\
2 \text { (6-24時) }\end{array}$ \\
\hline
\end{tabular}

Case 2の2方向とも通常渋滞するケースは，その半分の年 発生数365回/年(1日1回)と設定した.

同様に，2年間の渋滞データから3号神戸線の交通事故 等による突発渋滞の箇所別頻度を図-9に示す．図-9(a)は 深夜・早朝(0-6時), 図-9(b)は日中・夜間(6-24時)の時間带 である. 最も多く発生する区間が深夜・早朝(0-6時)33キ ロポスト付近で15件/2年，日中・夜間(6-24時) 38キロポス 卜付近で149件/2年である.これらからCase 3とCase 4の年 発生数をそれぞれ，15件/2年 $\fallingdotseq 8$ 件/年，149件/2年 $\fallingdotseq 75$ 件/ 年とした.

Case5は，日中・夜間(6-24時)に1方向で通常渋滞が発生 しているときに反対方向で突発渋滞が発生するケースで あり, 後述する通常渋滞の平均発生時間3時間 $(1.5$ 時間 $\times 2$ 回/日)の間に発生する頻度を 75 件/年 $\times 3$ 時間/18時間(日 中・夜間 $) \fallingdotseq 13$ 件/年と仮定する.

Case6は，その発生確率が極めて小さいため，2年間の 渋滞データからは発生頻度をモデル化することが困難で あり，ここでは仮定として，1件/20年=0.05件/年とする.

\section{c) 車両速度}

2004年9月のある平日の3号神戸線における芦屋一深江 間の5分間平均速度の時刻変化を図-10に示寸. 午前8時 台に通常淽滞が発生しており，5分間平均速度が20 $40 \mathrm{~km} / \mathrm{h}$ に低下している，それ以外の時間帯は概衫 $60 \mathrm{~km} / \mathrm{h}$ である.このデータから通常走行の車両速度を $60 \mathrm{~km} / \mathrm{h}$, 通常啮滞の車両速度を $30 \mathrm{~km} / \mathrm{h}$ と寸る. 突発渋滞の車両速 度は，文献7)から $2 \mathrm{~km} / \mathrm{h}$ とした。各走行状態と車両速度 の関係を表-5に示す。 


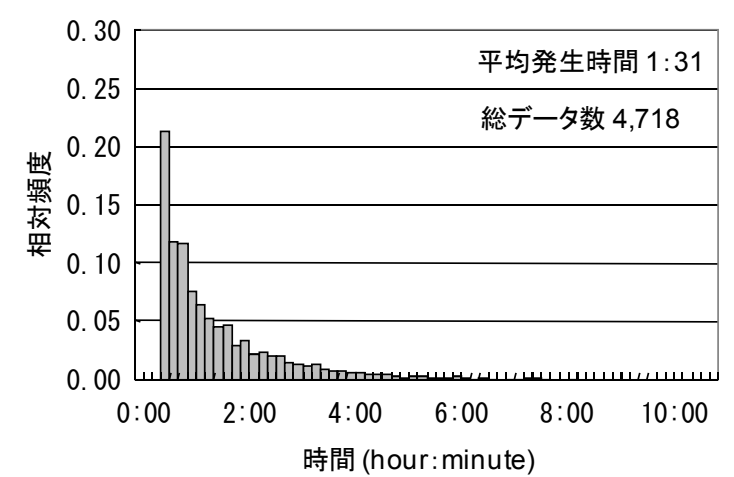

(a) 日中・夜間(6-24 時) の通常涉滞

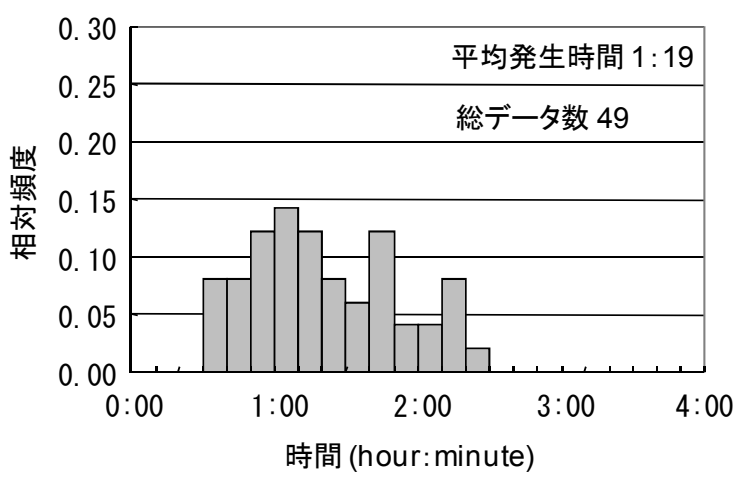

(b) 深夜・早朝(0-6 日寺)の突発渋滞

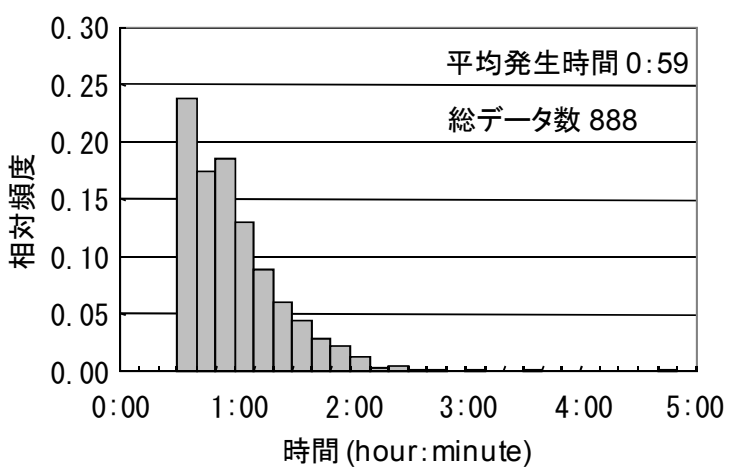

(c) 日中・夜間(6-24時) の突発渋滞

図-11 渋滞時間の頻度分布

\section{d) 渋滞時の車両列長}

2年間（2003～2004年）の3号神戸線における日中・夜 間(6-24時)の通常渋滞, 深夜 - 早朝(0-6時)の突発渋帯, 日中・夜間(6-24時)の突発渋滞の渋滞時間の頻度分布を それぞれ，図-11(a), (b), (c)に示す. それぞれの渋帯の平 均発生時間と前項で設定した車両速度の積から対象橋梁 を通過する車両列長を表-5のとおり設定した。なお，渋 滞時間を確率的にモデル化するにはデータが不十分なた め，ここでは，渋滞時間を平均值で代表させた。

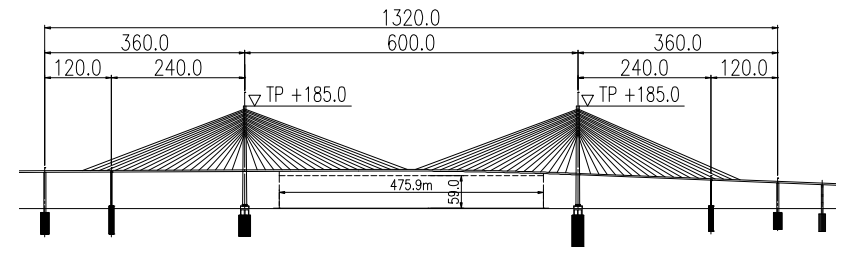

(a) 橋梁全体図

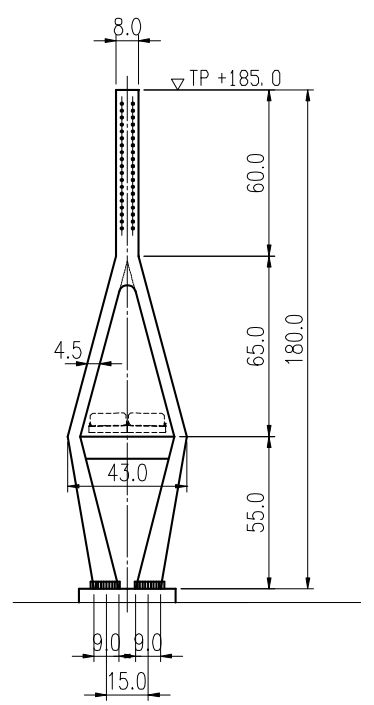

(b) 塔

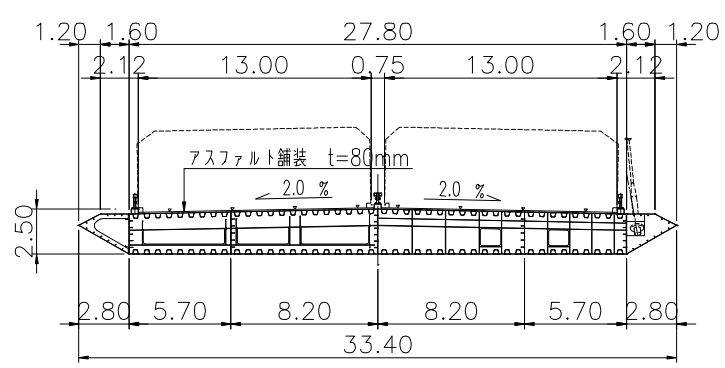

(c) 主林断面

図-12 対象とする斜張橋

\section{3. 斜張橋の車両列載荷シミュレーション}

\section{(1) 対象橋梁とシミュレーション手法}

対象とする斜張橋は，図-12に示す上下6車線，全長 $1,320 \mathrm{~m}$ （中央支間 $600 \mathrm{~m}$ ）の5径間連続鋼斜張橋である. 斜張橋に対する車両列載荷のモンテカルロシミュレーシ ヨンの流れを図-13に示す. 確率分布に従う乱数の発生 により多数の車両列を生成して, 斜張橋の橋梁モデルに 配置する. 乱数で設定する車両列のパラメータを図-14 に示す. 車種, 車重, 車長, 車間距離の4つのパラメー 


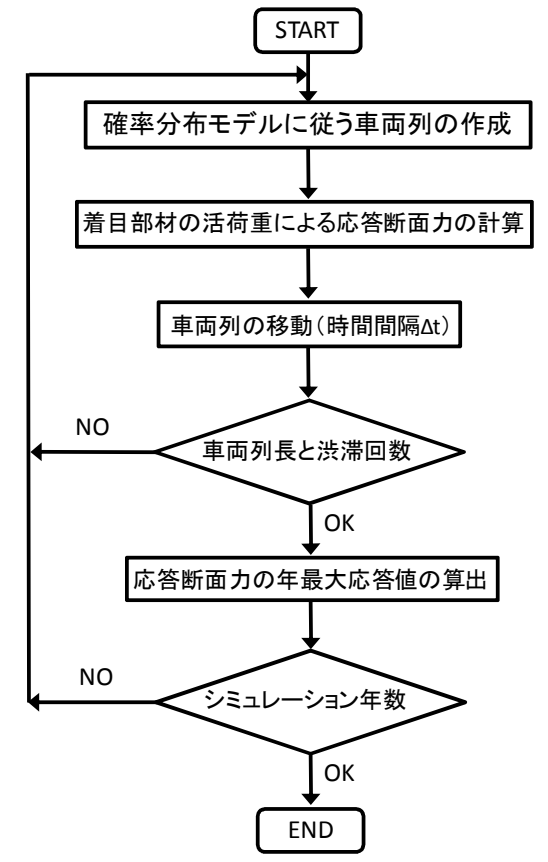

図-13 車両列載荷のモンテカルロシミュレーションの流れ

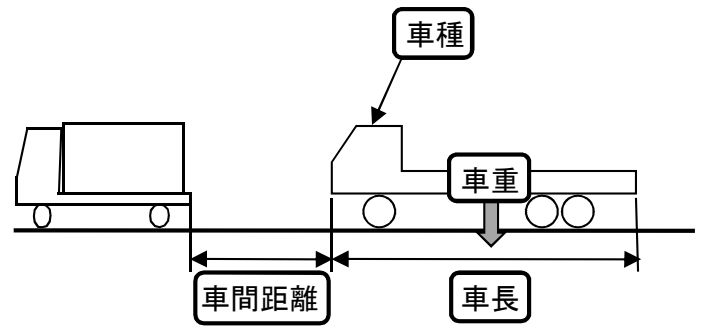

図-14 乱数で設定する車両列のパラメータ

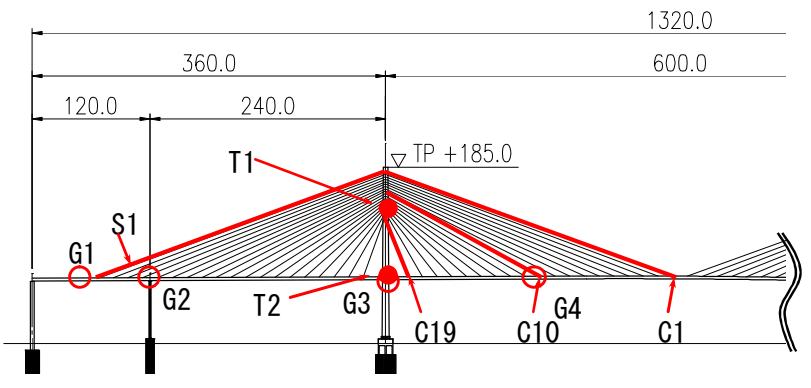

図-15 最大応答を算出する斜張橋の着目部材

タである，軸重，軸位置，軸数は車種に従属するパラメ ータとして前述のとおり設定した，車両列を時間間隔 $\Delta t$ で移動させ, 移動毎に着目部材の活荷重応答を計算して 渋滞1回当たりの最大応答值を求める. これを設定した 車両列長と渋滞回数を満足するまで繰り返して年最大応 答を算出し，シミュレーション年数分繰り返して年最大 応答值の分布を推定する. なお，時間間隔 $\Delta t$ は $0.5(\mathrm{sec})$ と
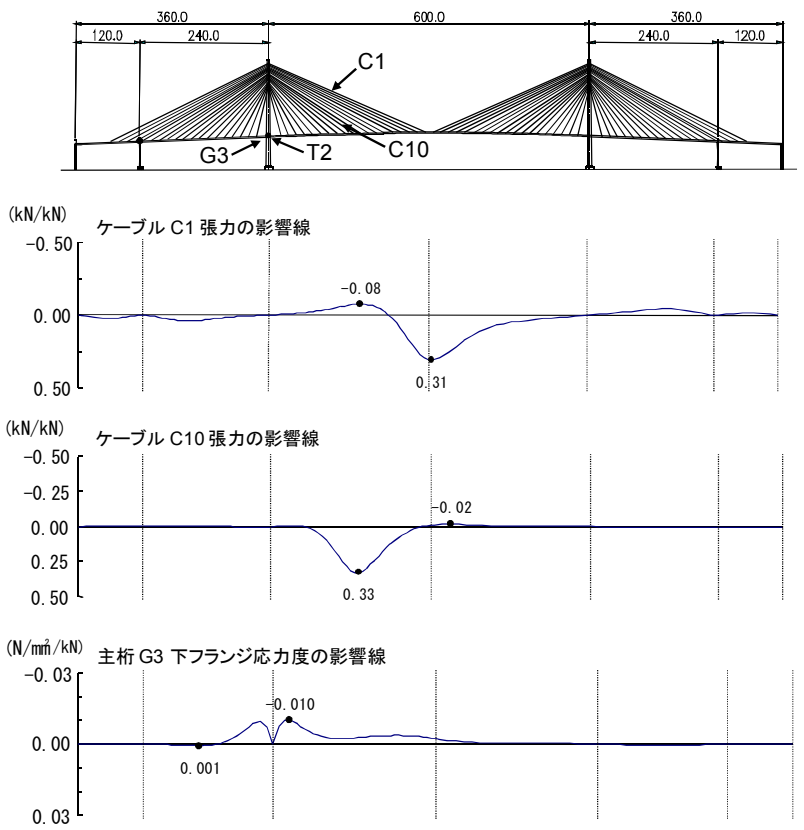

$\left(\mathrm{N} / \mathrm{mm}^{2} / \mathrm{kN}\right)$ 塔 T2 フランジ応力度の影響線

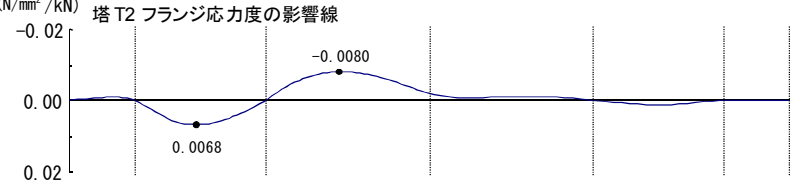

図-16 斜張橋のケーブル，主桁，塔の影響線の例

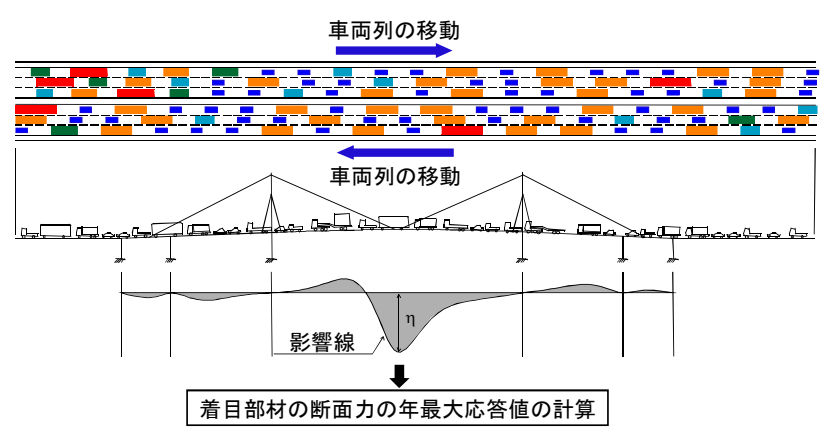

図-17 車両列の載荷，移動，着目部材の断面力の年最大応答 值の計算

1.0( $\mathrm{sec})$ のケースについて試算し, 年最大応答值に対す る $\Delta t の$ 影響が小さかったことから，ここでは， $\Delta t=1.0(\mathrm{sec})$ とした.

最大応答を算出する斜張橋の着目部材を図-15に示す. 中央径間側のケーブル $\mathrm{Cl}, \mathrm{C} 10, \mathrm{C} 19$ の張力, 側径間側ケ 一ブルS1の張力, 鋼製塔の上部 $\mathrm{T} 1$ と主标位置T2の面外 方向（橋軸方向）フランジの軸力と曲げの合成応力度, 主桁G1, G2, G3, G4 デッキ及び下フランジの軸力と曲げ の合成応力度であり，いずれも死荷重+活荷重で断面が 決定する部材である. 着目部材の活荷重による応答断面 


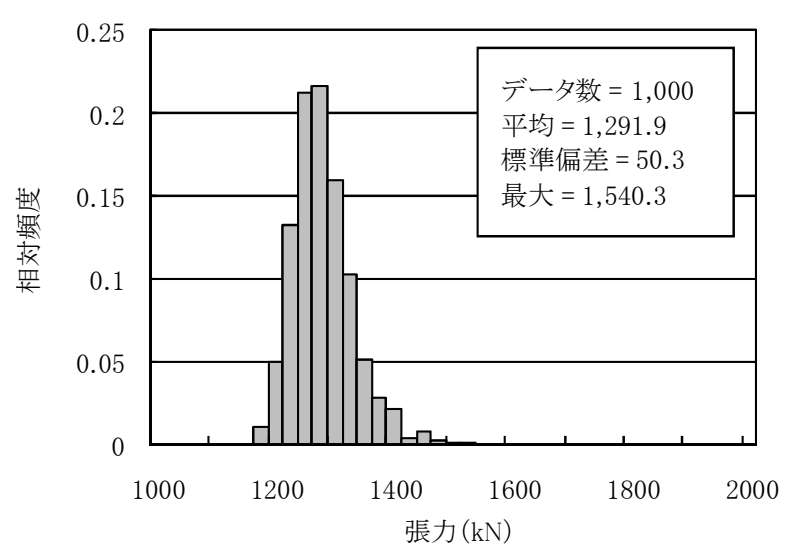

図-18 ケーブル C1 の張力の年最大応答值の頻度分布(Case3)

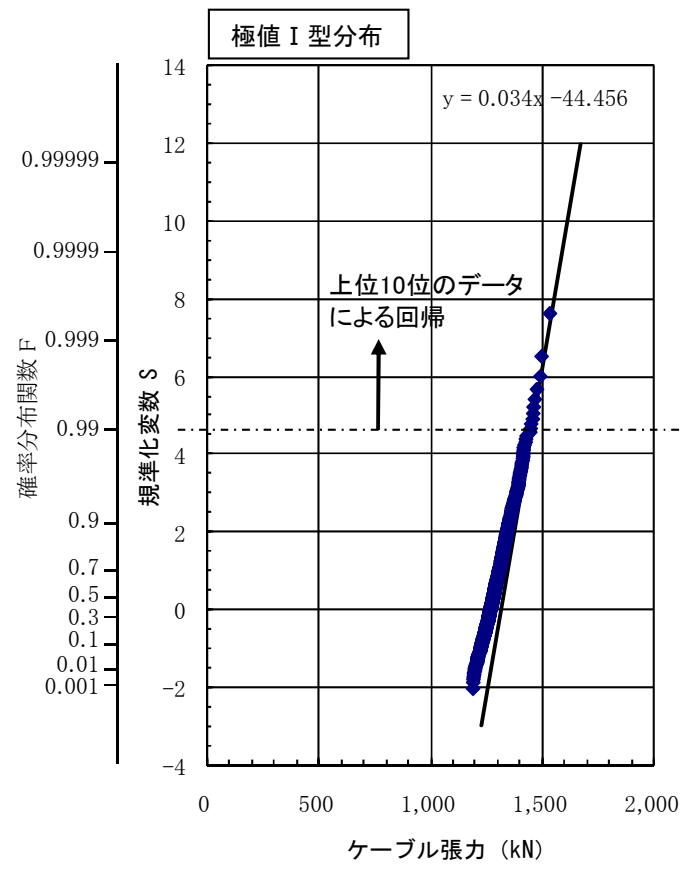

図-19 ケーブル $\mathrm{Cl}$ の張力の年最大応答值の極值 $\mathrm{I}$ 型分布への 当てはめ(Case3)

カFは式(1)により計算する.

$$
F=\sum_{j=1}^{6}\left(\sum_{i=1}^{n_{j}} W_{i} \cdot \eta_{i}\right) \cdot \alpha_{j}
$$

ここに, $W_{i}: i$ 番目の軸重, $\eta_{i}: i$ 番目の軸重位置の着目 部材の断面力の影響線縦距, $\alpha_{j}: j$ 番目の車線の荷重の 横方向分配率（ケーブル定着間で1-0分配と仮定）， $n_{j}$ : $j$ 番目の車線上の軸重の数である. なお, 活荷重載荷に よる衝撃は，対象が中央支間 $600 \mathrm{~m} の$ 長大斜張橋であり， その影響が小さいと考えられるので考慮しないこととし

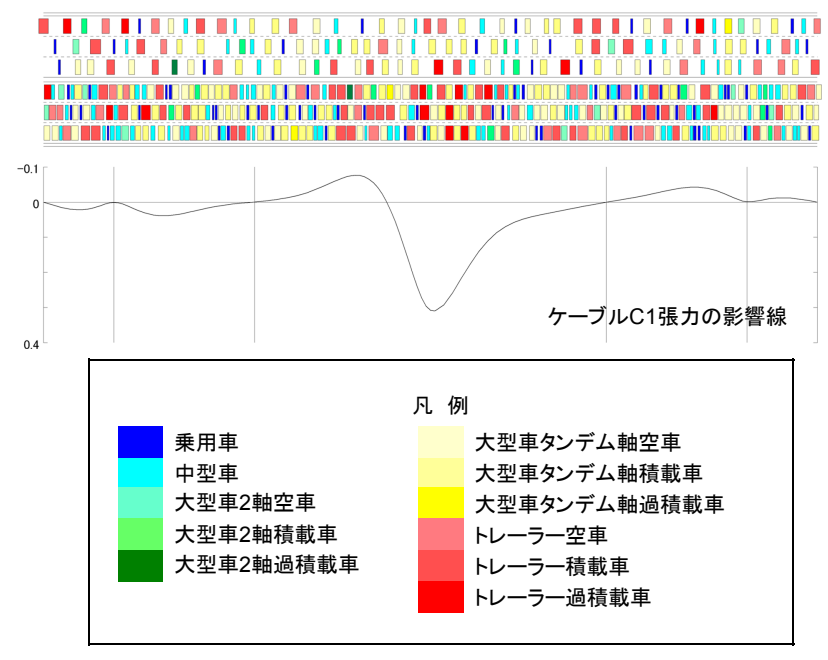

(a) 車種

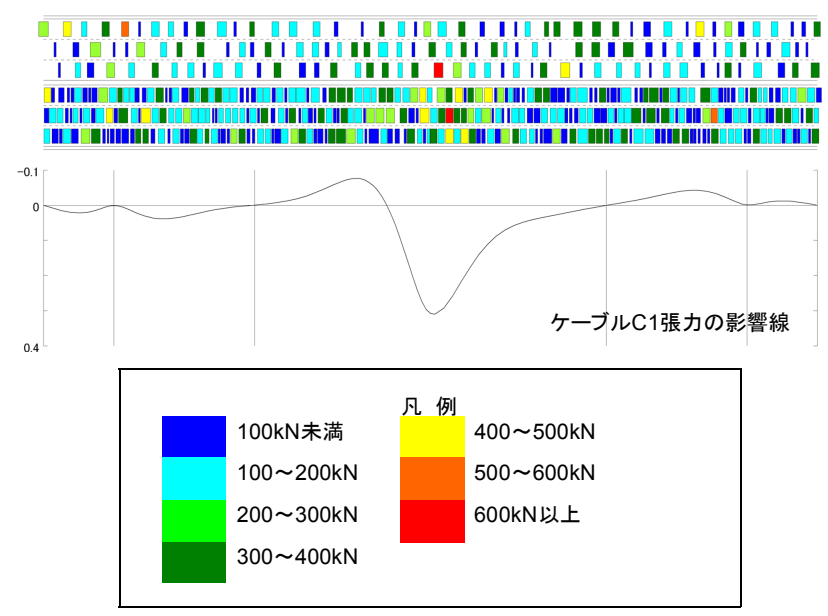

(b) 車重

図-20 ケーブル $\mathrm{Cl}$ の張力の最大応答出現時の車両の載荷状態 (Case3)

た.

対象とした斜張橋のケーブル，主桁，塔の影響線の 例を図-16に示す．着目点によって影響線は様々な形状 となる. 車両列の載荷, 移動, 着目部材の断面力の年最 大応答值の計算のイメージを図-17に示す.

シミュレーション年数（ここでは1,000年とする．） 分の年最大応答值を計算し, Hazenの方法で大きい順に 並へ，極值I型分布に当てはめ，設定した再現期間に対 応する再現期待值を算出する. Case3の中央径間側ケー ブル $\mathrm{Cl}$ の張力を例に，年最大応答值の頻度分布を図-18 に，極值I型分布に当てはめた結果を図-19に示す．なお， 年最大応答值分布の上位データが重要であるため, 極值 I型分布への当てはめは，上位10位までのデータで回帰 している.

Case3の1,000年のシミュレーションでケーブルC1の張 


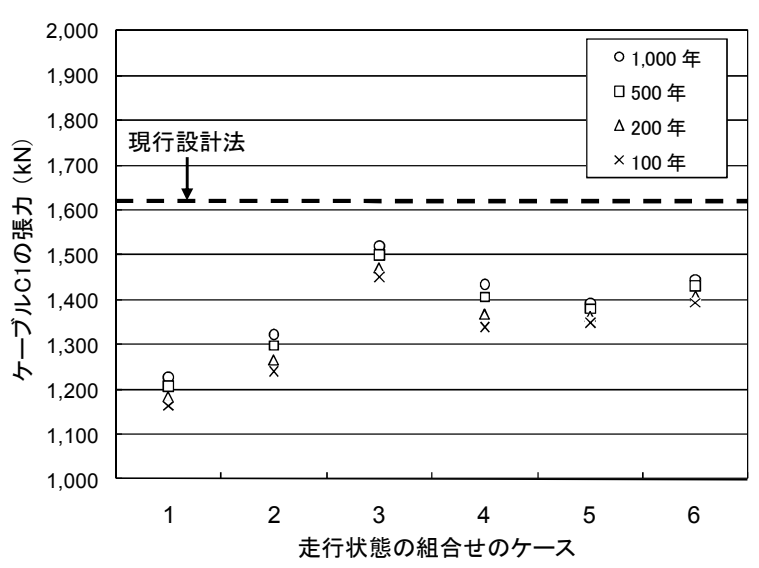

図-21 走行状態の組合せによるケーブル $\mathrm{Cl}$ の張力の再現期待 值

表-6

再現期待值と期間100年最大值分布の非超過確率との関係

\begin{tabular}{|c|c|}
\hline $\begin{array}{c}\text { 再現期間 } \\
\text { (年) }\end{array}$ & $\begin{array}{c}\text { 期間100年最大值分布 } \\
\text { の非超過確率 }(\%)\end{array}$ \\
\hline 100 & 37 \\
\hline 200 & 61 \\
\hline 500 & 82 \\
\hline 1,000 & 90 \\
\hline
\end{tabular}

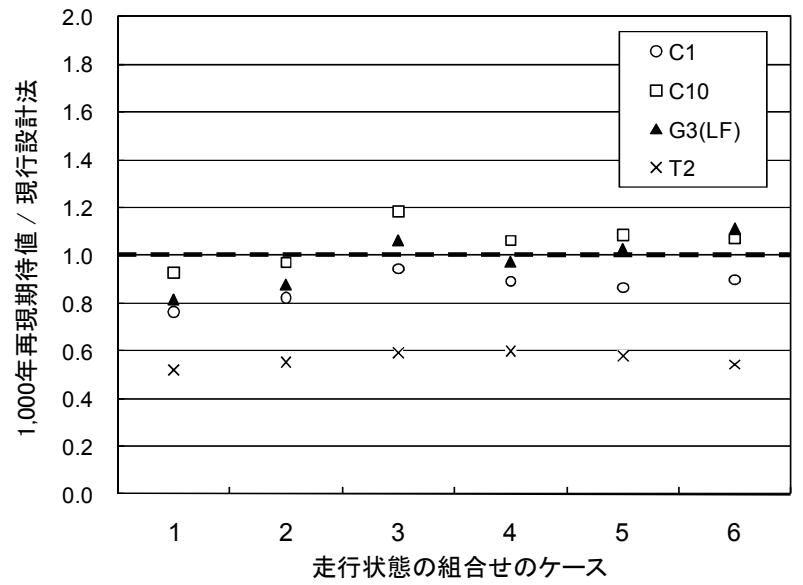

図-22 走行状態の組合せによる現行設計法に対する 1,000 年再 現期待值の比の比較

力の最大応答が出現した時の車両列の載荷状態を図-20 に示す．図-20(a)が車種，図-20(b)が車重を表示している。 上側車線が通常走行で下側車線が突発渋滞である。 ケー ブルC1の張力への寄与率が高い影響線縦距の大きい範 囲に大型車，トレーラーが固まっており，200kN以上の 車両が各車線に2〜 5台連行しているのがわかる.

\section{(2) シミュレーション結果}

\section{a) 各走行状態の比較}

表-4に示した走行状態の組合せによる部材の年最大応 答值の再現期待值を比較する. ここでは, 斜張橋の最も

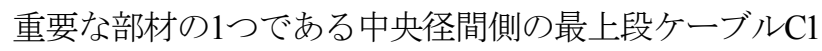
の張力に着目する. Case1からCase6の走行状態によるケ ーブルC1の張力の再現期待值を図-21に示す．各ケース の100, 200, 500, 1,000年再現期待值を示している．100, 200, $500,1,000$ 年再現期待值と斜張橋の供用期間を 100 年とし た場合の期間100年最大值分布の非超過確率との関係は 表-6に示すとおりである. 走行状態の組合せの比較では Case3が最も大きな再現期待值を示している. Case 4, 5, 6 もCase 1,2に比べて大きな再現期待值を示す.

また，等価L荷重を影響線載荷する現行設計法による ケーブル張力の活荷重応答值(1,610kN)を図-21中に破線 で示している. 各ケースの1,000年再現期待值が現行設 計法のケーブル張力を超過することはない.

次に, ケーブルC1以外の着目点について, 走行状態 の組合せによる部材の年最大応答值の 1,000 年再現期待 值を比較する．着目点は，図-16に示した影響線形状の 異なるケーブル $\mathrm{Cl}, \mathrm{C} 10$, 主林 $\mathrm{G} 3$ (下フランジ，以下， LF と表す，)，塔T2である．各着目点の現行設計法に対す るシミュレーションの1,000年再現期待值の比を図-22に 示す．ケーブル $\mathrm{Cl}(\mathrm{O}$ 印), $\mathrm{C} 10(\square$ 印)は，6ケース中でCase3 が最も大きな応答を示す．塔T2(×印)は，Case 4 が最も大 きな応答を示すが，Case3もほぼ同じレベルの応答を示 す. 主桁G3(LF) (ム印)は, Case6,Case3の順で大きな応答 を示す．ただし，前述のようにCase6の年発生数は渋滞 データに基づくものでなく, 仮定した発生数であること に留意する必要がある。これらから図-15に示した斜張 橋のケーブル，主桁，塔の着目点に対して，Case3の走 行状態の組合せによる活荷重応答に着目すれば，各着目 点のほぼ最大応答を捉えることができると判断した.

\section{b) 着目部材の断面力の 1,000 年再現期待値}

前節の結果をもとに, Case3に着目した部材の年最大 応答值の1,000年再現期待值を比較する. 図-15に示した 着目点の現行設計法に対する 1,000 年再現期待值の比を 図-23に示寸．主桁G1〜G4の添え字(D) と(LF)は，それぞ れ，主枌のデッキ，下フランジを表しており，主枌 $\mathrm{G} 1$ $\sim \mathrm{G} 4$, 塔 $\mathrm{T} 1$ ～ 22 は軸力と曲げの合成応力度, ケーブル S1, C1, C10, C19は張力を算出し, 現行設計法に対する比 を算出している．着目点間で現行設計法に対する 1,000 年再現期待值の比がばらついており, 実際の活荷重応答 に近いと考えられるシミュレーションの再現期待值と現 行設計法の活荷重応答值には整合性がないことがわかる. また, G3(LF), C10の2点では1.0を超過しており，1,000年 再現期待值（期間100年最大值分布の $90 \%$ 非超過確率值 相当）に対して，現行設計法が必ずしも安全側の設計と 


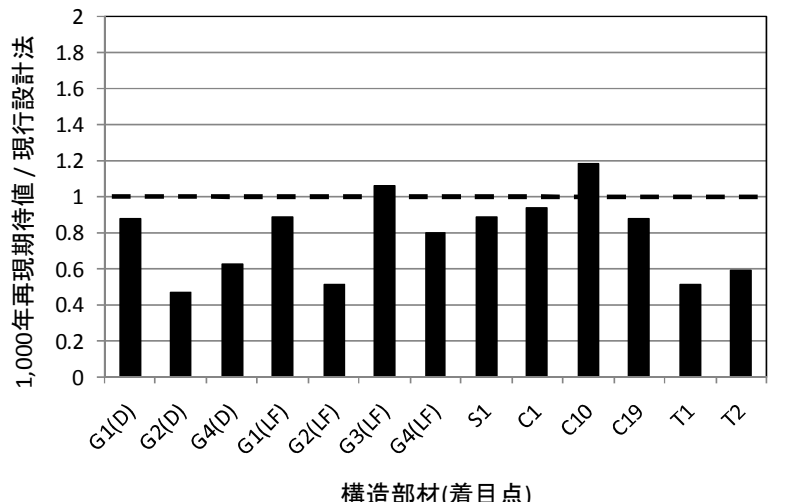

図-23現行設計法に対する 1,000年再現期待值の比(Case3)

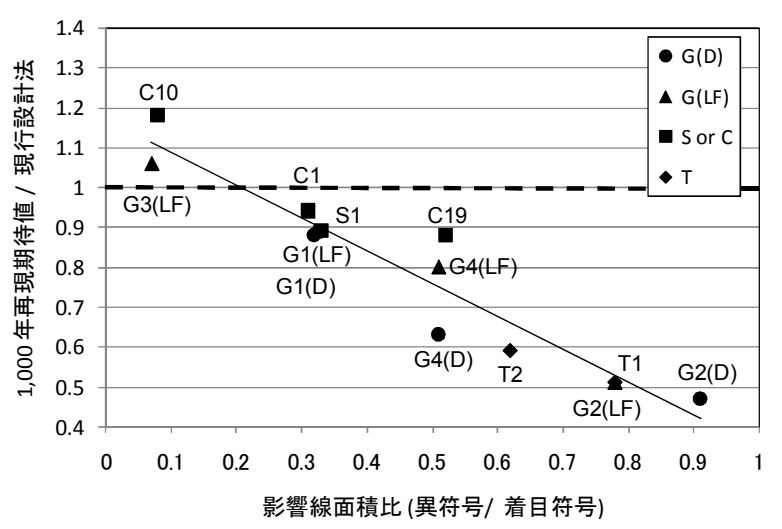

図-24 影響線面積比と現行設計法に対する 1,000 年再現期待值 の比の関係

いうわけではない. なお，図-23でG3(D)の比を示してい ないのは，G3(D)が塔部付近の主桁デッキで死荷重によ る軸圧縮力が卓越する箇所であり，断面決定に及ぼす活 荷重の影響が小さいことによる.

次に, 図-23の現行設計法に対する 1,000 年再現期待値 の比が着目点間でばらつく要因について考察する．現行 設計法では，等価L荷重を影響線の着目符号側の夕に載 荷するのに対して，シミュレーションでは着目点の影響 線の形状に関わらず，仮定した確率分布モデルに従う車 両列が載荷されるので，着目点の影響線の異符号側の面 積の大小が両者の結果の相違に影響していることが推察 される，そこで，影響線の異符号側の面積を定量的に表 すパラメータとして, 該当する断面力の影響線の着目符 号に対する異符号の面積比（以下，影響線面積比之呼 ぶ. ）に着目する。

各着目点の影響線面積比と現行設計法に対する 1,000 年再現期待值の比の関係を図-24に示す，同図中の凡例 は着目部材の種類を示しており, 実線は全13データの回 帰直線である. 着目点の構造部材の種類に関係なく, 影
響線面積比が大きくなると現行設計法に対する 1,000 年 再現期待値の比が小さくなる傾向がある. これは，影響 線の異符号面積が大きいと, シミュレーションでは異符 号範囲に車両列が載荷される影響が大きくなり, 異符号 側に活荷重を載荷しない現行設計法に比べてシミュレー ションの活荷重応答が低減するためである，一方，異符 号面積が小さいと, 影響線縦距と軸重の積で得られるシ ミュレーションの活荷重応答と着目符号側のみに活荷重 を載荷する現行設計法の差が小さくなるため, 現行設計 法に対する 1,000 年再現期待值の比が 1 に近づく. なお, 影響線面積比が 0.1 付近でシミュレーションの活荷重応 答が現行設計法よりも最大 $20 \%$ 程度大きくなるのは，後 述するシミュレーションから得られる活荷重強度が等価 L荷重よりも大きいためと考えられる.

以上から, 斜張橋の着目点によって現行設計法の活 荷重応答とシミュレーションの 1,000 年再現期待值が整 合しないのは, 影響線の着目符号と異符号の面積比が異 なっていることが要因の1つであることがわかる．性能 照査型設計におけるより実態に近い設計活荷重を設定す るためには, 影響線の異符号側に載荷される車両列を考 慮する必要があると考えられる.

\section{c) 活荷重強度}

年最大応答が得られた時刻の車両列の載荷状態をシ ミュレーションから抽出し, 活荷重強度に換算して現行 の等価L荷重との比較を行う。換算する活荷重強度は, 1,000年のシミュレーションにおける着目点の上位10位ま での年最大応答が出現した時刻の上下車線の車両列の車 重の合計値から算定する橋軸方向 $1 \mathrm{~m}$ 当たりの平均活荷 重強度である.上位10位までの車両列の車重の平均を取 るのは，1位の年最大応答が出現した時刻の車両列のみ を取り出すと, 車両列の車重のばらつきのためシミュレ ーションのケースによっては活荷重強度を正しく評価で きない場合があるからである. なお， 1,000年のシミュ レーションで上位10位までの最大応答出現時の平均を取 ると，ほぼ $100 \sim 1,000$ 年再現期待值相当の活荷重強度が 算定される.

影響線載荷長とシミュレーション最大応答上位10位の 平均活荷重強度の関係を図-25に示す。ここで, 影響線 載荷長とは，着目符号側の主要な載荷範囲の長さであり, 着目点の年最大応答に支配的な影響を及ぼす活荷重を抽 出する目的でこのパラメータに着目した. 平均活荷重強 度は, 影響線載荷長範囲の車両列の車重の平均である.

図-25中の実線は，等価L荷重の等分布荷重 $p_{1}$ と $p_{2}$ を平均 した荷重強度，破線はその1.2倍を表している．等価L荷 重では，支間長が横軸のパラメータであるが，ここでは， 支間長と影響線載荷長を同じパラメータと見なしている. シミュレーションから得られた平均活荷重強度は, 等価L荷重よりも大きく, 等価L荷重の1.2倍程度が上限 


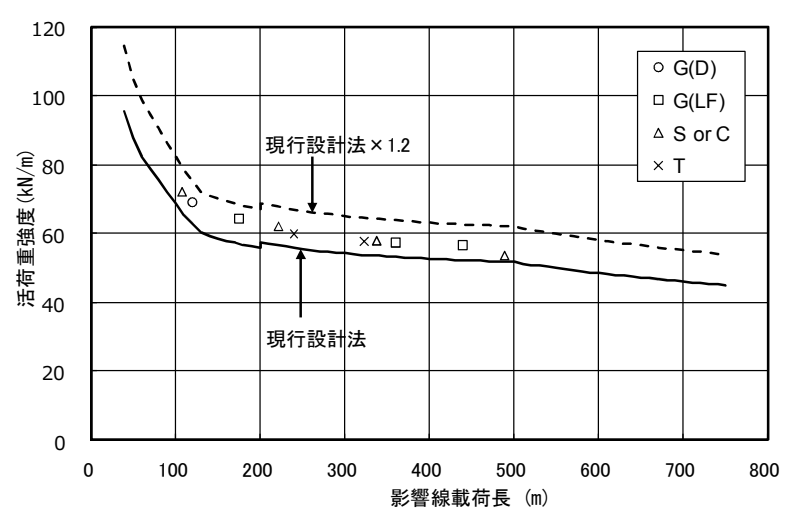

図-25影響線載荷長とシミュレーション最大応答上位 10 位の 平均活荷重強度の関係

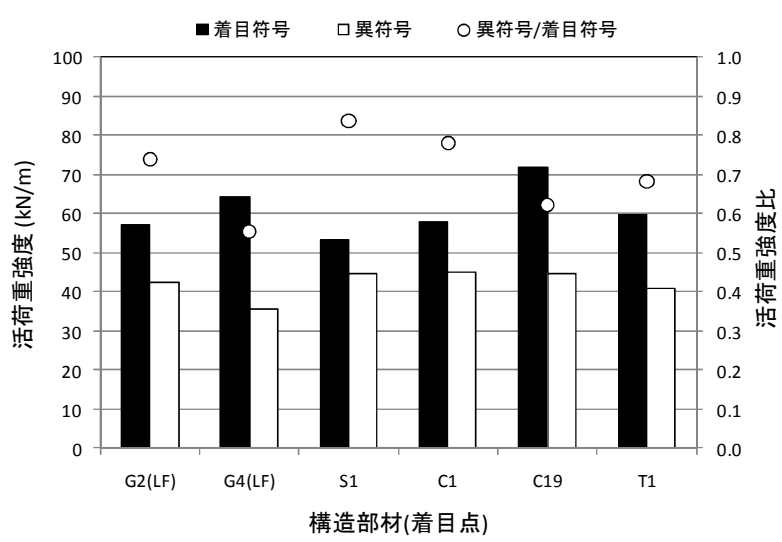

図-26 着目符号と異符号の影響線範囲の平均活荷重強度の比 較

となっているのがわかる. 図-24の影響線面積比が 0.1 付 近で現行設計法に対する 1,000 年再現期待值の比が最大 20\%程度大きくなるのは，シミュレーションの平均活荷 重強度が等価L荷重よりも大きいためと考えられる.

次に，1,000年のシミュレーションから得られる最大 応答上位10位の平均活荷重強度について，着目符号側と 異符号側を比較する. 比較する着目点は, 影響線の着目 符号と異符号の面積が拮抗しているG2(LF), G4(LF), S1, C1, C19, T1の6点とした。着目符号と異符号の影響線範囲の 平均活荷重強度の比較を図-26に示す．図-26中に着目符 号に対する異符号の活荷重強度比を○印で併せて示して いる. 年最大応答の上位10位が出現する時の異符号側の 平均荷重強度が着目符号側と比較して極端に小さいこと はなく，着目符号に対する異符号の活荷重強度比を見る と，異符号側に着目符号の $55 \%$ \% $85 \%$ 程度の活荷重強度 相当の車両列が載荷されており，着目符号側の夕に載荷 する現行設計法とシミュレーション結果の違いが明らか である。

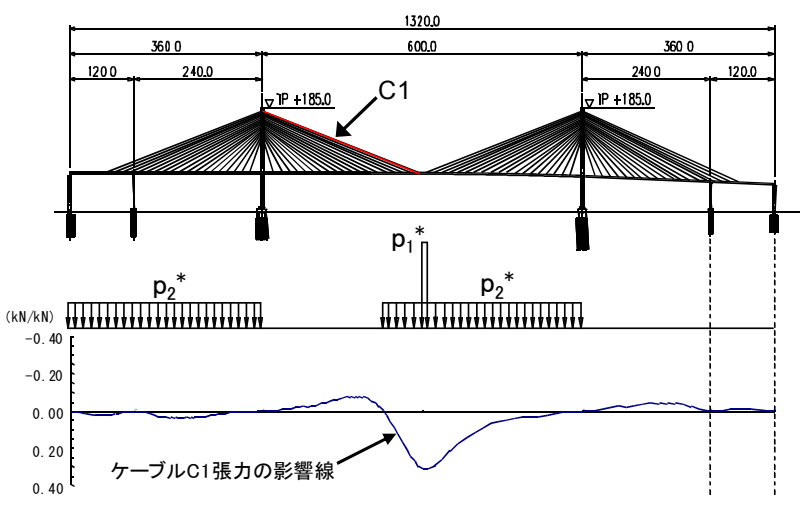

(a) 現行設計法(等価 L 荷重)

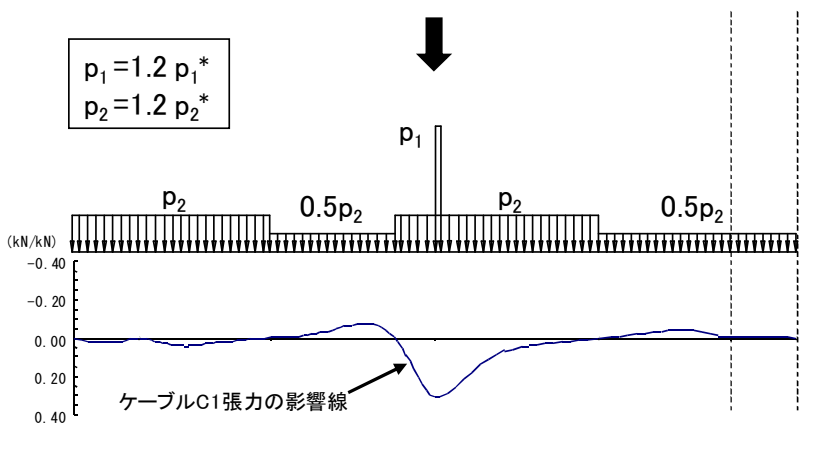

(b) シミュレーション結果に基づく提案設計法

図-27 法の提案

\section{4. シミュレーション結果に基づく設計活荷重と 載荷方法の提案}

\section{（1）設計活荷重と載荷方法}

シミュレーション結果をもとに都市高速道路の交通 特性を反映した斜張橋の設計活荷重を提案する. 活荷重 強度を図-25から現行の等価L荷重の1.2倍とする。また, 橋梁に最も不利となるように影響線の着目符号側のみに 載荷する方法でなく，シミュレーションにおいて活荷重 応答が最大となる時の車両列の載荷状態を反映し，影響 線の異符号側にも50\%の活荷重強度を載荷するものとす る５0\%としたのは，図-26の異符号側の活荷重強度の 下限側（安全側）を採用したことが理由である.シミュ レーション結果に基づき提案する設計活荷重とその載荷 方法（以下，提案設計法と呼ぶ. ）を図-27に示す.

\section{(2) 部分安全係数法による設計照査式への適用}

提案した設計活荷重は，100年～1,000年再現期待值相 当の活荷重を採用しているので，限界状態設計法である 部分安全係数法による設計照査式に適用し，提案設計法 の特徵を現行設計法との比較から考察する. 死荷重+活 
荷重時の設計照査式を式(2)で与える

$$
R / \gamma_{R} \geqq \gamma_{g} \cdot\left(\gamma_{D} S_{D}+\gamma_{L} S_{L}\right)
$$

ここに, $R$ : 公称強度, $\gamma_{R}$ : 公称強度に対する部分安全 係数, $\gamma_{g}$ : 構造物の重要度を表す部分安全係数, $\gamma_{D}$ : 死 荷重に対する部分安全係数, $S_{D}$ : 公称死荷重による荷重 効果, $\gamma_{L}$ : 活荷重に対する部分安全係数, $S_{L}$ : 公称活荷 重による荷重効果である.

ここで用いる部分安全係数を表-7に示す．文献8)を参 考に設定した．表-7には，許容応力度法に対応させた各 係数も示している． $\gamma_{R}$ は, 主桁・塔で1.05, ケーブルで 1.15 と設定した. 鋼板で構成される主桁・塔に比較して, ケーブルは腐食, 架設誤差等の影響を大きく受けるため,

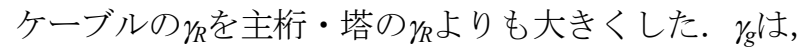
構造物の重要度として1.0（普通），1.1（重要）, 1.2 (最重要) とあるが8)，斜張橋は建設コストが高く，損 傷が生じた場合の補修コストも高いことから斜張橋の $\gamma_{g}$ は，1.2 (最重要）とした． $\gamma_{D}$ は, 鋼橋の死荷重のばらつ きの調査結果7),9)参考に1.1とした。 $\gamma_{L}$ は, シミュレーシ ヨン結果により 100年〜 1,000年再現期待值相当の活荷重 強度を採用しているため1.1とした。許容応力度法にお ける降伏耐力に対する主桁・塔の鋼板の安全率は1.7, ケーブルの安全率は1.85である.

表-7に示した部分安全係数を式(3)として整理した場合 の係数 $A, B$ を表-8に示す.

$$
\begin{gathered}
R \geqq A \cdot S_{D}+B \cdot S^{*}{ }_{L} \\
S_{L} \fallingdotseq 1.2 S^{*}{ }_{L}
\end{gathered}
$$

ここに, $R$ : 公称強度, $S_{D}$ : 公称死荷重による荷重効果, $S^{*}{ }_{L}$ : 等価L荷重による荷重効果, $S_{L}$ : 公称活荷重による 荷重効果である．ただし， $S_{L}$ は影響線の異符号範囲に載 荷寸る活荷重効果のため, 厳密に $S_{L}^{*}$ の1.2倍ではない.

表-7で設定した部分安全係数を整理した係数 $A, B$ は, 許 容応力度法に相当する係数 $A, B$ と比較すると小さくなる.

\section{（3） 斜張橋の主要断面と年最大応答の1,000年再現期待 值の比較}

提案設計法と式(2)を用いて斜張橋の断面設計を行い, 現行設計法による断面と比較する. 主桁, 塔, ケーブル の断面積と鋼重の比較をそれぞれ，表-9，10に示す．表-

\begin{tabular}{|c|c|c|c|c|}
\hline \multirow{2}{*}{$\begin{array}{c}\text { 部分安全 } \\
\text { 係数 }\end{array}$} & \multicolumn{2}{|c|}{ 本検討で設定した係数 } & \multicolumn{2}{|c|}{ 許容応力度法 } \\
\hline & 主桁 · 塔 & ケーブル & 主桁 · 塔 & ケーブル \\
\hline$\gamma_{R}$ & 1.05 & 1.15 & 1.7 & 1.85 \\
\hline$\gamma_{g}$ & 1.2 & 1.2 & 1.0 & 1.0 \\
\hline$\gamma_{D}$ & 1.1 & 1.1 & 1.0 & 1.0 \\
\hline$\gamma_{L}$ & 1.1 & 1.1 & 1.0 & 1.0 \\
\hline
\end{tabular}
8に示したように, 現行設計法の許容応力度法に比べて
表-7 部分安全係数

表-8 式(4)における係数 $A, B$

\begin{tabular}{|c|c|c|c|c|}
\hline 着目点 & $\begin{array}{c}\text { 現行設計法 } \\
\text { (1) }\end{array}$ & $\begin{array}{c}\text { 提案設計法 } \\
\text { (2) }\end{array}$ & (2) / (1) & 備考 \\
\hline 主桁G1 & $\begin{array}{c}1.88 \mathrm{~m}^{2} \\
(\mathrm{SM} 490 \mathrm{Y})\end{array}$ & $\begin{array}{c}1.63 \mathrm{~m}^{2} \\
(\mathrm{SM} 490 \mathrm{Y})\end{array}$ & 0.87 & $\begin{array}{c}\text { カッコ内 } \\
\text { は鋼材質 } \\
\text { を表す }\end{array}$ \\
\hline 主桁G2 & $\begin{array}{c}1.32 \mathrm{~m}^{2} \\
(\mathrm{SM} 490 \mathrm{Y})\end{array}$ & $\begin{array}{c}1.21 \mathrm{~m}^{2} \\
(\mathrm{SM} 490 \mathrm{Y})\end{array}$ & 0.92 & \\
\hline 主桁G3 & $\begin{array}{c}1.18 \mathrm{~m}^{2} \\
(\mathrm{SM} 490 \mathrm{Y})\end{array}$ & $\begin{array}{c}1.18 \mathrm{~m}^{2} \\
(\mathrm{SM} 400)\end{array}$ & 1.00 & $\begin{array}{c}\text { 最小板厚 } \\
\text { で決定 }\end{array}$ \\
\hline 主桁G4 & $\begin{array}{c}1.18 \mathrm{~m}^{2} \\
(\mathrm{SM} 400)\end{array}$ & $\begin{array}{c}1.18 \mathrm{~m}^{2} \\
(\mathrm{SM} 400)\end{array}$ & 1.00 & $\begin{array}{c}\text { 最小板厚 } \\
\text { で決定 }\end{array}$ \\
\hline ケーブルS1 & $10,197 \mathrm{~mm}^{2}$ & $8581 \mathrm{~mm}^{2}$ & 0.84 & $\begin{array}{l}\Phi 7 \mathrm{~mm}- \\
\text { SPWC }\end{array}$ \\
\hline ケーブルC1 & $9735 \mathrm{~mm}^{2}$ & $8119 \mathrm{~mm}^{2}$ & 0.83 & $\begin{array}{l}\Phi 7 \mathrm{~mm}- \\
\text { SPWC }\end{array}$ \\
\hline $\begin{array}{c}\text { ケーブル } \\
\mathrm{C} 10\end{array}$ & $7196 \mathrm{~mm}^{2}$ & $6272 \mathrm{~mm}^{2}$ & 0.87 & $\begin{array}{l}\Phi 7 \mathrm{~mm}- \\
\text { SPWC }\end{array}$ \\
\hline $\begin{array}{c}\text { ケーブル } \\
\text { C19 }\end{array}$ & $4194 \mathrm{~mm}^{2}$ & $3502 \mathrm{~mm}^{2}$ & 0.84 & $\begin{array}{l}\Phi 7 \mathrm{~mm}- \\
\text { SPWC }\end{array}$ \\
\hline 塔T1 & $\begin{array}{c}1.44 \mathrm{~m}^{2} \\
(\mathrm{SM} 490 \mathrm{Y})\end{array}$ & $\begin{array}{c}1.20 \mathrm{~m}^{2} \\
(\mathrm{SM} 490 \mathrm{Y})\end{array}$ & 0.83 & \\
\hline 塔T2 & $\begin{array}{c}1.24 \mathrm{~m}^{2} \\
(\mathrm{SM} 490 \mathrm{Y})\end{array}$ & $\begin{array}{c}0.96 \mathrm{~m}^{2} \\
(\mathrm{SM} 490 \mathrm{Y})\end{array}$ & 0.77 & \\
\hline
\end{tabular}

\begin{tabular}{|c|c|c|c|c|}
\hline \multirow{2}{*}{ 倸数 } & \multicolumn{2}{|c|}{ 本検討で設定した係数 } & \multicolumn{2}{|c|}{ 許容応力度法 } \\
\cline { 2 - 5 } & 主桁・塔 & ケーブル & 主桁・塔 & ケーブル \\
\hline$A$ & 1.39 & 1.52 & 1.7 & 1.85 \\
\hline$B$ & 1.66 & 1.82 & 1.7 & 1.85 \\
\hline
\end{tabular}

表-9 主桁, 塔, ケーブルの断面積の比較

表-10 主椼, 塔, ケーブルの鋼重の比較

\begin{tabular}{|c|c|c|c|}
\hline 着目部材 & $\begin{array}{c}\text { 現行設計法 } \\
(1)\end{array}$ & $\begin{array}{c}\text { 提案設計法 } \\
(2)\end{array}$ & $(2) /(1)$ \\
\hline 主桁 & $197,000 \mathrm{kN}$ & $194,000 \mathrm{kN}$ & 0.98 \\
\hline ケーブル & $19,300 \mathrm{kN}$ & $16,500 \mathrm{kN}$ & 0.85 \\
\hline 塔 (2 基) & $80,800 \mathrm{kN}$ & $73,600 \mathrm{kN}$ & 0.91 \\
\hline 合計 & $297,100 \mathrm{kN}$ & $284,100 \mathrm{kN}$ & 0.96 \\
\hline
\end{tabular}

小さい係数の提案設計法では, 現行設計法と比較して着 目点の断面積が $0 \sim 20 \%$ 程度減少する. 主桁, 塔, ケー 


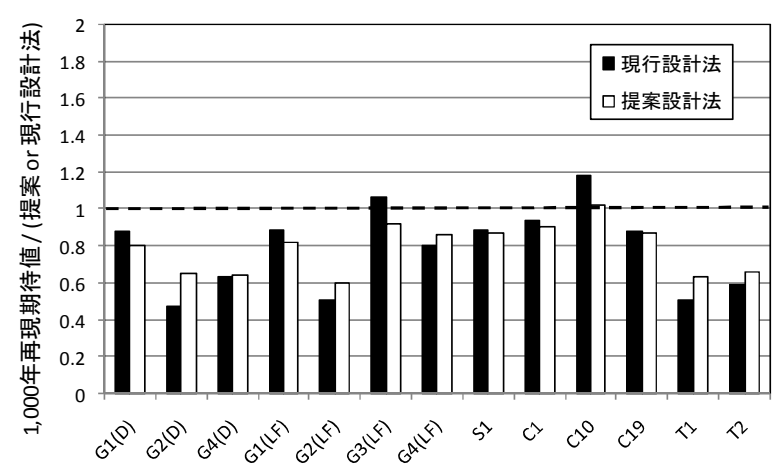

構造部材(着目点)

図-28 提案設計法及び現行設計法に対する 1,000 年再現期待值 の比

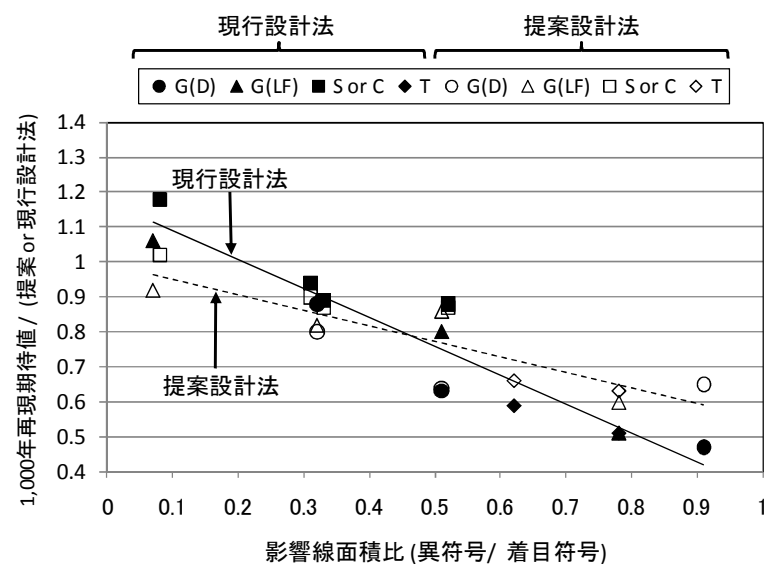

図-29 影響線面積比と提案設計法及び現行設計法に対する 1,000 年再現期待値の比の関係

ブルの合計鋼重は4\%の減少になる.

提案設計法により設計した斜張橋に対して, 同様の車 両列載荷のシミュレーションを実施し，着目点の年最大 応答の 1,000 年再現期待值を算出する. 各着目点の提案 設計法及び現行設計法に対する 1,000 年再現期待值の比 を図-28に示す．提案設計法に対する年最大応答の 1,000 年再現期待值の比は，現行設計法で1.0を超過していた G3(LF), C10で小さくなり，ほぼ1.0以下となる. 期間100 年最大值分布の $90 \%$ 非超過確率值相当の 1,000 年再現期待 值に対して現行設計法よりも安全な設計となる.

次に，各着目点の影響線面積比と提案設計法及び現行 設計法に対する 1,000 年再現期待值の比の関係を図-29に 示す. 凡例の白抜きの印が提案設計法，黒塗りの印が現 行設計法である。図-29中の破線及び実線は，それぞれ の 13 データの回帰直線である。影響面積比が 0.5 より さい範囲では提案設計法の比が現行設計法の比より減少

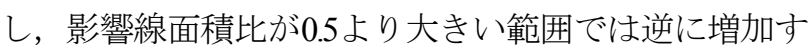
ることで回帰直線の傾きが水平に近づく．設計值と 1,000 年再現期待值の整合性が向上すると共に，着目点 間の設計值に対する 1,000 年再現期待值の比のばらつき が小さくなったと解釈できる。 これは，提案設計法が影 響線の着目符号だけでなく，異符号側にも活荷重を載荷 する方法であり，現行設計法の着目符号側のみに載荷す る方法と比較して影響線面積比の影響が緩和されたこと が理由と考えられる。

\section{5. 安全性評価指標の比較}

提案設計法の合理性について考察するため, 死荷重+ 活荷重時の終局限界状態を対象に，提案設計法と現行設 計法の安全性評価指標の比較を行う。

安全性評価指標を式(5)で定義する.

$$
S I=X_{u} / X_{1,000}
$$

ここに, SI : 安全性評価指標， $X_{u}$ : 終局限界状態の活 荷重に対する保有耐力（終局限界に相当する荷重効果か ら死荷重に相当する荷重効果 $\gamma_{D} S_{D}$ を差し引いた活荷重に 対する保有耐力）， $X_{1,000}$ : 年最大応答の 1,000 年再現期待 值の活荷重効果である. 主桁・塔の終局限界状態は，引 張に対して鋼板の降伏強度，圧縮に対して補剛板の座屈 耐荷力, 及び座屈安定照査とする. ケーブルの終局限界 状態は，降伏強度（ $0.7 \%$ 全伸びに対する耐力）とする. 各着目点の提案設計法及び現行設計法による安全性評価 指標SIの比較を図-30に，安全性評価指標SIの頻度分布の 比較を図-31に示す. 部分安全係数法の設計照査式を適 用して，現行設計法の許容応力度法に比較して小さい係 数を用いているため, 提案設計法のSIは, 現行設計法の SIに比べて全体的に小さくなる傾向がある，しかし，現 行設計法のSIが 2.9 (=G3(LF)) から 6.5 (=C19)の範囲

$(\Delta S=3.6)$ で着目点間でばらつくのに対し，提案設計法 のSIは， 2.0 (=G3(LF))から4.9(=G2(D))の範囲（ $\Delta S=2.9 ）$ に 狭まっており，SIの頻度分布からも着目点間のSIのばら つきが小さくなっていることがわかる.このことから， 提案設計法は現行設計法に比べて構造部材の安全性を着 目点間で同じレベルに近づけることができ，合理的な設 計になると考えられる.

なお，現行設計法のケーブルC19のSIが大きいのは， ケーブルC19の活荷重に対する死荷重の比率が $80 \%$ あ, 現行設計法の死荷重に対する安全率を1.7としているた め, かなり安全な設計となっていることが理由である. 


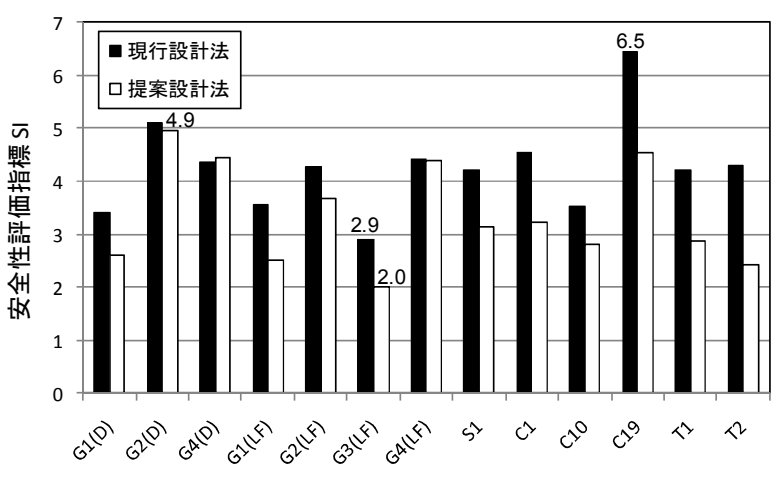

構造部材(着目点)

図-30 安全性評価指標 SIの比較

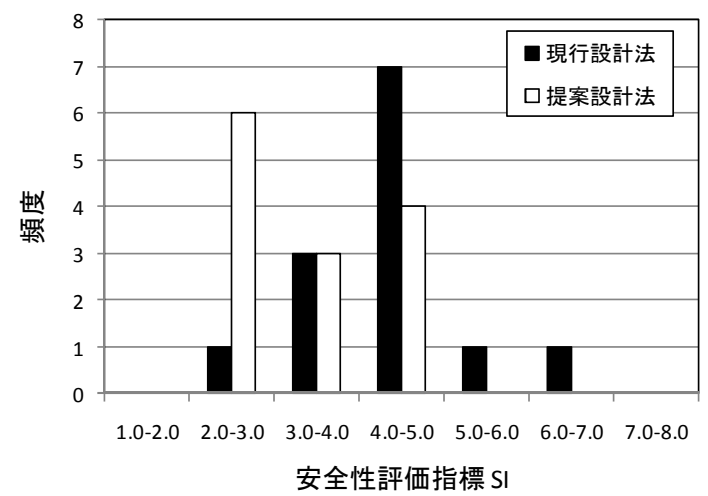

図-31 安全性評価指標 $S I$ の頻度分布

\section{6. まとめ}

中央支間長 $600 \mathrm{~m}$ の斜張橋を対象として都市高速道路 の交通特性，特に都市部で頻繁に発生する渋滞特性を反 映した設計活荷重を提案することを目的に交通調査デー 夕に基づく車両列載荷のシミュレーションを実施した. シミュレーション結果と等価L荷重を影響線載荷する現 行設計法の比較を行い, 性能照査型設計の観点から地域 の都市高速道路の交通特性に即した合理的な設計活荷重 とその載荷方法を提案し，安全性評価指標の比較からそ の合理性を示した.

以下に本研究で得られた主な知見を示す.

1) 現行設計法の活荷重応答とシミュレーションから得ら れた活荷重応答の 1,000 年再現期待値（期間100年最大 值分布の $90 \%$ 非超過確率相当）の比は，ケーブル，主 桁, 塔の着目点間でばらつく，その要因は，図-24に 示したように着目点の構造部材の種類に関わらず, 影響線の着目符号と異符号の面積比が異なっている ためである.

2) 影響線面積比が大きいと現行設計法に対する 1,000 年
再現期待値の比が小さくなる傾向がある.これは, 異符号の面積が大きいと, シミュレーションでは異 符号範囲に車両列が載荷される影響が大きくなり， 異符号側に活荷重を載荷しない現行設計法に比べて シミュレーションの活荷重応答が低減するためであ る。一方, 異符号面積が小さいと, 影響線縦距と軸 重の積で得られるシミュレーションの活荷重応答と 着目符号側のみに活荷重を載荷する現行設計法の差 は小さくなる.

3) 1,000年のシミュレーションで上位10位までの最大応答 出現時の平均活荷重強度（100 1,000年再現期待值相 当）は，図-25に示したように等価L荷重よりも大き く，等価L荷重の1.2倍程度が上限となる.

4) 年最大応答の上位 10 位が出現する時の異符号側の平均 荷重強度は着目符号側と比較して極端に小さいこと はなく, 着目符号に対寸る異符号の活荷重強度比で, 55\% 85\%程度の車両列が異符号側に載荷されており， 現行設計法の影響線載荷法とシミュレーション結果 の違いが明らかである.

5) シミュレーション結果をもとに，等価L荷重の1.2倍の 活荷重強度と影響線の異符号側に着目符号側の $50 \%$ の 活荷重強度を載荷する設計法を提案した。提案設計 法を用いると，図-29に示したように影響線面積比の 影響が緩和され，設計值と 1,000 年再現期待值との整 合性が向上すると共に，着目点間のばらつきが小さ くなる.

6) 死荷重+活荷重時の終局限界状態に関する安全性評価 指標の比較から, 提案設計法は現行設計法に比べて 構造部材の安全性を着目点間で同じレベルに近づけ ることができ，合理的な設計となる.

謝辞 : 本研究は, 大阪湾岸道路西伸部橋梁技術検討会, 大阪湾岸道路西伸部活荷重ワーキンググループ（座長 : 古田均関西大学教授）において議論された内容をまとめ たものである. 多くの貴重な意見を賜った委員各位をは じめ，同ワーキンググループを主催した国土交通省近畿 地方整備局阪神国道事務所に深く感謝の意を表寸る.

\section{参考文献}

1) (社) 日本道路協会 : 道路構造令の解説とその運用, pp.1-38, 2004.6

2) (社)日本道路協会 : 道路橋示方書 - 同解説 I 共通編, pp.11-20, 2002.3

3) 本州四国連絡橋公団：上部構造設計基準 - 同解説, 1995.7

4) 明田修, 北沢正彦：都市高速道路の設計活荷重につ いての検討，橋梁と基礎，Vol.27, No.6, pp.23-32, 1993.6

5) 北田俊行, 中井博, 野口二郎, 岩廣真悟 : 実働活荷 重にもとづいた連続桁橋，および斜張橋設計用の活 
荷重モデルについて，構造工学論文集，Vol.44A， pp.71-80, 1998.3

6) 齊藤展生, 村越潤, 西川和廣 : 活荷重シミュレーシ ヨン解析による四径間吊橋の設計活荷重に関する検 討，構造工学論文集，Vol.45A, pp.1253-1262, 1999.3

7) 阪神高速道路公団, (財)阪神高速道路管理技術センタ 一：阪神高速道路公団設計荷重(HDL)委員会報告書,
阪神高速道路の設計荷重体系に関する調查研究, 1986.12

8) (社)日本鋼構造協会 : 土木構造物の性能設計ガイド ライン, pp.87-93, 2001.10

9）（社)日本道路協会：荷重検討班第 2 次報告書，限界状 態設計法分科会, 1989.3

\title{
A STUDY ON TRAFFIC LIVE LOAD FOR A CABLE-STAYED BRIDGE BASED ON THE TRAFFIC CHARACTERISTICS OF AN URBAN EXPRESSWAY
}

\author{
Tsutomu NISHIOKA, Yoshihei HORIE and Osamu AKETA
}

Monte Carlo simulation is conducted in order to study the traffic live load for a cable-stayed bridge in an urban expressway. A probabilistic model of the traffic live load is developed by the traffic survey data. The study shows that the difference between the simulation and the conventional design method results from the differnce between the dominant and opposite influence line area. A new design traffic live load is proposed from this study. It turns out that the proposed design metod is more reasonable than the conventional one from the comparison of the safety index among structural members. 